\title{
Gertrude Bell's Resolution of a Disputed Inscription
}

\begin{abstract}
Alan H. CADWALLADER*
The 1889 extension of the railway line from İzmir to Denizli and Dinar brought an unprecedented volume of travellers, tourists and traders through the Maeander and Lycus Valleys. Sir Charles Wilson, British military consul-general in Anatolia (1879-1882), turned his knowledge of the Ottoman empire to encouraging the increasing traffic of English-speaking sightseers along the British-backed Ottoman Railway Company's infrastructure. ${ }^{1}$ Guidebooks for the French and German markets were also produced in repeatedly up-dated editions. ${ }^{2}$ How extensive was that traffic can be deduced from the hotels accompanying many of the stations along the route, ${ }^{3}$ whose staff also organized horses and carriages to cover the short distances from hotels to ancient sites in the area - for a fee. Colossae, for example, lay three miles south from the stop at Bucall. Wilson enticed prospective explorers with the knowledge that a tour of the biblical "seven churches of Asia" would take a mere ten or eleven days. He added that travellers "not pressed for time" could include, within a seventeen-day itinerary, visits to Magnesia ad Maeandrum, Aphrodisias and Tabae. ${ }^{4}$ It was assumed that Colossae would be included under the visit to Laodikeia and Hierapolis; Goncalı was the usual launching-station for the latter two sites. ${ }^{5}$ This required greater use of horse or carriage. Even so, it was a considerable shortening of the allocation for the tourist circuit begun in the seventeenth century, which demanded at least two weeks' hard riding. ${ }^{6}$ Thomas Smith (1638-1710) had added a hand-written marginal note to his copy of Rycaut's much-plagiarizing and inaccurate book on the churches in Turkey, that "hundreds ... have visited these Churches, as they now lye in their ruines", adding "with greater care and better observation" than the publication's author. ${ }^{7}$
\end{abstract}

* Prof. Dr. Alan H. Cadwallader, Centre for Public and Contextual Theology, Charles Sturt University, Canberra, ACT, Australia (acadwallader@csu.edu.au; https://orcid.org/0000-0003-3423-1125).

${ }^{1}$ Wilson 1895.

${ }^{2}$ Joanne - Isambert 1881; Baedeker 1905.

${ }^{3}$ Another English-language travel-guide described the Railway Company's hotel at Goncalı as "excellent” (Hogarth et al. 1908, 195).

${ }^{4}$ Wilson 1895, 107.

${ }^{5}$ Hogarth et al. 1908, 195 noting that special arrangements could be made with the train driver to stop at a bridge beyond Goncalı, "and there mount horses sent on ahead from the hotel." Later writers made Goncall the base for all three sites (Hawley 1918, 186).

${ }^{6}$ Brennan 1999, 70; In 1855, the Reverend William John Beamont's diary records 18 days for his horse tour. See his diary titled "Visit to the Seven Churches of Asia", Ms 706 at the Warrington Library Museum and Archives (UK), ff. 5a-27b. I express my thanks to Ms Hilary Chambers, then archivist at the library for permission to view this manuscript.

${ }^{7}$ Rycaut 1679, 31 marg. Smith's copy of the book is held by the London Library; some of his annotations gain a "T.S." at the end, as if Smith wanted posterity to know his assessment. I am grateful to the staff at the London Library for arranging my access. Rycaut had made considerable use of material gathered by Smith 
Before the advent of mass-production of photographic records, ${ }^{8}$ intrepid itinerants could supplement their practised diary notes with printed postcards of the Seven Churches, a visual proof of their voyages (fig. 1).

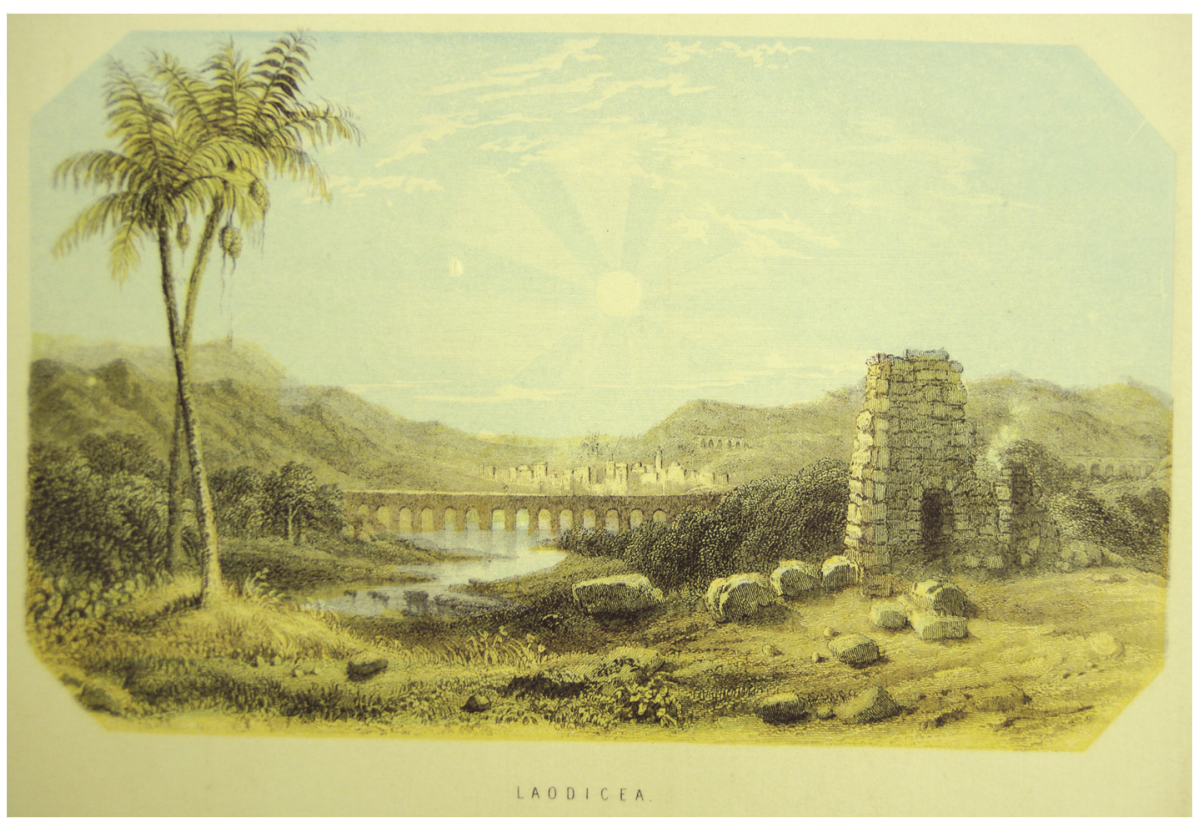

Fig. 1) The colour postcard of Laodicea stuck into the 1855 diary of the Reverend William John Beamont, ${ }^{9}$ showing remarkably intact sections of aqueduct

The railway added to the efficiency of contact and recording, indeed had become a point of reliance for epigraphers and surface archaeologists, with their survey maps and eventual ease of travel. ${ }^{10}$ But it also cultivated a long-observed characteristic of stones in Asia Minor - their propensity to move, or, strictly, to be moved. ${ }^{11}$ Railway officials and managers of adjoining hotels knew of the particular antiquarian interests of many travellers on the Ottoman Railway and obliged those interests with samples either to whet appetites for the sites themselves or to provide a vicarious visit with an artefact less arduously discovered. Indeed, even the route of the railway, at least in its final stage to Dinar, may well have been determined by archaeological influence. ${ }^{12}$ This was the irony of (or atonement for?) many stones being crushed or converted to new building requirements as the iron machinery ground its way through the landscape. Gertrude Bell, the

and by another chaplain of the Levant Company, the Reverend Doctor John Luke. In neither case did he return the borrowed material and, if Smith's marginalia is typical, played rather loosely with its contents (Cadwallader 2008, 329-330).

${ }^{8}$ See, for example, Svoboda 1869 . The photographs themselves were also sold singly and in sets by the publisher. On the importance of Svoboda's work and of visual representations of the seven churches to promote research and tourism, see Herring 2015.

${ }^{9}$ Beamont 1855 Diary, Warrington Library, Ms 706 f.2a.

${ }^{10}$ See Sterrett 1888, 425, making mention of the Ottoman Railway survey already underway. Compare Ramsay 1897, xvii, map reliant on the "Ottoman Railway Survey".

${ }^{11}$ Greenhalgh 2012, 143 no. 24.

12 Thonemann 2011, 79. 
intrepid linguist, archeologist, and sometime spy, saw the (unequal) trade-off, even as she made good use of the advances in transportation:

... the railway has come near, the plains will fill up, and neither Syrian fellah nor Turkish soldier can be induced to spare walls that can be turned to practical uses. Therefore let those who saw it when it yet stood unimpaired, cherish its memory with gratitude, and without too deep a regret. ${ }^{13}$

It meant, as we shall see, that the other momentous invention of the nineteenth century, the camera, was her constant companion, as she sought to capture what she knew was passing away.

\section{The Disputed Inscription}

The small station at Appa, en route to Dinar, became a resting-place for a number of inscribed stones drawn from various sites along the line of the railway. One inscription in particular is the focus of this paper, the epitaph of Dionoisios and his family. The inscription is noted by three travellers and well-known epigraphers of the late nineteenth-early twentieth centuries: Georg Weber, William Mitchell Ramsay and Georges Cousin. Weber was the first we know of to record the inscription. He published it in 1893, four years after the railway was extended to Dinar. In fact, his small inventory of five inscriptions shows clearly that he simply alighted from the train at a succession of stops to make a note of an inscribed stone at one particular station or another (Dinar, Appa and Goncalı - all villages at the time) with one stop (Sundurlü) allowing a forty-minute return hike to gather another. ${ }^{14}$ This alone points to a prolific if not systematic "adornment" of railway stations with items known to attract European interest. ${ }^{15}$

Ramsay's copy was published in his two-volume work, The Cities and Bishoprics of Phrygia. ${ }^{16} \mathrm{He}$ headed the inscription with "Laodiceia: from the engineers of the Ottoman Railway." The reference to the "Ottoman Railway" indicates that, while he was dependent in many instances of inscriptions on earlier surveys ${ }^{17}$, he too was reliant on a station stop to make his transcription, though he did not disclose the station nor the nature of the involvement of the "engineers". He makes no mention of Weber's transcription, even though he bestows considerable approbation on his work ${ }^{18}$ and cites Weber's 1893 article for an inscription from Anaua-Sanaos. ${ }^{19}$ Ramsay included the inscription under the general category of "Christian Inscriptions of S. W. Phrygia." The only support for the inclusion in the category was the name Irene, which he asserted "was favoured by the Christians." He acknowledged however, that this was not enough to cement the argument. He also noted two other stelai by way of comparanda for the form of the stone, both of which make mention of a "heroon", both of which have slightly more evidence suggestive of a

\footnotetext{
${ }^{13}$ Bell 1907, 44.

${ }^{14}$ Weber 1893, 206-207. 2019).

${ }^{16}$ Ramsay 1897,542 no. 408.

${ }^{17}$ Ramsay 1883.

${ }^{18}$ Ramsay 1895, 441, 462, 513.

${ }^{19}$ Ramsay 1895, 233 no. 83.
}

${ }^{15}$ This is one aspect omitted from Michael Greenhalgh's brilliant studies on the destruction of and purloining from ancient sites, even as the railway ostensibly widened access to them (Greenhalgh 2013 and 
Christian dedicant. ${ }^{20} \mathrm{~A}$ sketch is provided for one (no. 380). It is possible that Ramsay may have meant no. 371 not no. 372 as his comparison, given that the former does have a sketch of the stele that is a little similar to the design in his no. 380. However, the forms are sufficiently distinct as to suggest a different form of tombstone, which therefore leaves in abeyance any clarity about the Dionoisios epitaph. Ramsay's use of the term "stele" may have had a more general reference in the nineteenth century; to modern eyes it signals a flat stone of narrow depth with a tongue at its base to insert into a solid block. Such a type of epitaph is known from Colossae but hardly merits the notice of peculiarity that seems often to attach to Colossae's tombstones. William Ainsworth had called them "rude, grotesque-shaped pedestals"21; Ernst Renan dubbed them "bizarre". ${ }^{22}$

The third record of the same inscription comes from Georges Cousin. In 1898, he had stopped at what he calls "Kato-Appa" Station in the course of tracking the march of Cyrus the Younger, with Xenophon's Anabasis "dans ma poche" in the relative comfort of his train compartment. ${ }^{23} \mathrm{He}$ availed himself of some of the inscriptions adorning the station precincts, including one that, although difficult to read, seemed to refer to the city of Sanaos, later confirmed as adjacent to Lake Anaua. Cousin knew of other copyists who had stopped at Appa and recorded some of the relocated inscriptions ${ }^{24}$, even correcting a previous reconstruction. But he made no reference to Weber or Ramsay regarding Dionoisios' epitaph.

These railway-dependent explorers across a six-year time span (approximately), from three different countries and writing in three languages respectively, seem, in the case of Ramsay and Cousin, not to have known or cared to register the earlier publication of the inscription. None of them described this particular stone, or gave measurements. Weber had provided measurements for three of the five inscriptions published in his brief article, but the two that he labelled as "aus Kolossai" (nrs 3 and 4, respectively at "Station Appa" and "Station Gondjeli") were devoid of any description or measurements. His designation as "from Colossae" for the Dionoisios epitaph (his no. 3) is probably repeated in Charles Wilson's 1895 edition of Macmillan's Handbook for Travellers: Asia Minor. Wilson had provided an excursus on Colossae in the course of which he noted the city necropolis "on the right bank" (meaning of the Lycus, facing west) that contained "some curiously shaped tombstones: - one is to be seen at Appa Station further on"25." Of course, the irrefutable connection between Wilson's cryptic reference and Weber's epitaph is lacking, because Wilson does not reveal the inscription. If, however, the connection could be made, it might explain why Weber did not care to provide the measurement details for the epitaph at Appa or the one at Goncal. He had previously written of a visit to the necropolis at Colossae, providing a brief mention of a number of gravestones and commenting on their peculiar shape (eigentumlicher Form $\left.{ }^{26}\right)$. He excused himself from a full description of their design by adding a sketch of one of the tombstones as an exemplar of the multiple instances he saw. Although he gave only one

\footnotetext{
${ }^{20}$ Ramsay 1897 , no. $372,530-533$ no. 380.

${ }^{21}$ Ainsworth 1844, 16.

${ }^{22}$ Renan 1869, 357.

${ }^{23}$ Cousin 1904, 232, 403, XLIX.

${ }^{24}$ Legrande - Chamonard 1893: 249-51.

${ }^{25}$ Wilson 1895, 104.

${ }^{26}$ Weber 1891, 198.
} 
inscription (now IGRR 4.871) - again as a template of an asserted common type (gewöhnlichen Form) - this was not the inscription included in his sketch (fig. 2). ${ }^{27}$

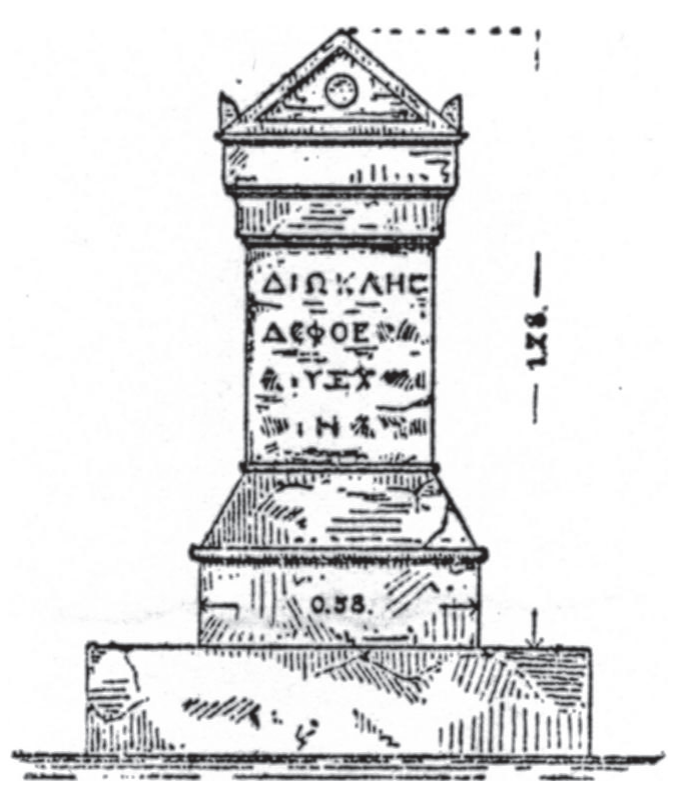

Fig. 2) Georg Weber's sketch of a typical tombstone in the Colossian necropolis, 1890
Important for my purpose here, is that he adds the measurements of the bomos $-1.78 \mathrm{~m}$ high, $0.58 \mathrm{~m}$ wide at the base of the shaft. He did not include the plinth in his measurement, even though the whole was cut as one piece. He allowed that the face of these bomoi might vary in design (with perhaps a symbol, a tool, a pitcher, a mirror). But he seems to have concluded that the distinctiveness of Colossae's epitaphs precluded the necessity of greater notation. Whether this extended to his Appa and Goncalı examples, published later, is unknown of course, but it seems to me likely, given his provision of the measurements of the other stones. Consequently, there is an opaqueness that attends the actual type of carved stone on which the inscription was found, given Ramsay's use of "stele" and the style indicated by Weber in his earlier article.

Weber was clear that the source of the Dionoisios epitaph at Appa station was "Kolossai". However, four years later, Ramsay, just as tersely, held the provenance to be "Laodiceia". Given that William Calder was a student of Ramsay, it probably is no surprise to find that Buckler and Calder's sixth volume of Monumenta Asiae Minoris Antiqua includes the Dionysios (sic!) epitaph in the supplementary list of sepulchral inscriptions of "Laodikeia". ${ }^{28}$ However, the inscription was not included in Thomas Corsten's catalogue of the inscriptions of Laodikeia ${ }^{29}$, even though eighteen of Ramsay's inscriptions in his Cities and Bishoprics, credited to Laodikeia, were entered. ${ }^{30}$ The inscription is included in the Packard Humanities Institute database in the form that

${ }^{27}$ Weber 1891, 198-199; I have argued elsewhere that this bomos sketch is of the then-intact epitaph of Dion the leather-worker (MAMA VI.44) (Cadwallader 2016, 171). See fig. 5 b) below.

${ }^{28}$ Buckler - Calder 1939, 142 no. 41*. They cited only Ramsay’s publication (not that of Weber or Cousin).

${ }^{29}$ I.Laodikeia Lykos.

${ }^{30}$ Indeed, one inscription, the second of Weber's 1893 inscriptions from Colossae (that is, seen at Goncalı station), Corsten has assigned to Laodikeia (IK 49.104). Buckler and Calder accepted Weber's allocation to Colossae (MAMA VI.43), as, earlier, had David Emrys-Evans (Emrys-Evans 1918, 163). On the other hand, Tullia Ritti, in republishing the inscription, has relied on Corsten's claim that Adolf Wilhelm had seen the inscription at Goncalı station and was assured by the station-master that it, along with others, was moved from Laodikeia (Ritti 2008, 260-261, no. 167). Unfortunately, neither Corsten nor Ritti cite the reference for Wilhelm; and Corsten's Bibliography and Concordance lacks any entry for Wilhelm. Ritti includes Wilhelm in her general bibliography, but the items contain no reference to Corsten's report. Corsten has advised me (personal communication 11/4/2020) that he was reliant on Wilhelm's notebooks, which I have not seen. Both Corsten and Ritti seem to assume that Weber's publication date provides the date of his visit, when this is clearly not the case for Weber's earlier article, which is dated " 8 August 1890 " though published in 1891 (Weber 1891, 199). If the same delay accompanied the 
Ramsay reconstructed, but an editorial addition is made "IK Laod. (not accepted)", ${ }^{31}$ presumably because it is not found in Corsten's catalogue. Michael Greenhalgh accepts Ramsay's notation of provenance, even tying it to a comment by Émile Le Camus that railway engineers had excavated a vast tract of Laodikeia in search of stones. On discovery of some more interesting ones, they were distributed - he cites Smyrna and Constantinople as the beneficiaries. ${ }^{32}$ Le Camus's published report dates to 1896 ("a year earlier" than Ramsay's publication). Greenhalgh assumes that it was Goncalı station where Ramsay's stone was located (the focus of Le Camus's discussion) and has confused two or more inscriptions naming a Dionysios. At the very least, Greenhalgh has missed Weber's publication and ignored the details of the commemoration described by Le Camus. ${ }^{33}$ Le Camus had borrowed, without acknowledgement, Weber's map of Colossae and the sketch of a funerary bomos, but, in spite of complaining about the lack of inscriptions at the site, ${ }^{34}$ did not include Weber's offerings from 1891 or 1893 . Given that his visit to the Lycus Valley appears to be April 1894, ${ }^{35}$ it seems that he was reliant for much of his information upon Georg

1893 article (which, unfortunately, is not dated in the text), then Weber and Wilhelm would likely have stopped at Goncalı station within temporal proximity of one another. It stretches credulity that Weber had not also asked about the provenance of the stone, though his comments are compact. The fact that he gives two stones from Appa station with a different provenance for each suggests that he had made inquiries. Certainly his fifth inscription, given as from Anava-Sanaos provides a brief account of its discovery. Ritti assumes that Corsten had thought the inscription lost; this is probably her inference from his use of Wilhelm's hand-copy. Corsten had referenced Buckler and Calder's photograph (MAMA VI.43, pl. 9) but declined to use it. Neither Corsten nor Ritti appear to have known of a squeeze of the stone held by the British Institute in Ankara (DM 946) and probably made by Anthony Sheppard in 1975-6, during a stint at the Denizli Museum. So the stone was certainly at the depot or the museum proper two decades before Corsten conducted his research. Weber was familiar with Laodikeia, providing the map that was used in Baedeker's travel handbook. The matter requires further assessment.

${ }^{31}$ Online link: https://epigraphy.packhum.org/text/271082.

${ }^{32}$ Greenhalgh 2013, 312; Le Camus 1896, 202.

${ }^{33}$ In fact, Le Camus's description matches in considerable detail another stele; see IK 49.98. This inscription had been published by Ramsay in the first volume of his Cities and Bishoprics (Ramsay 1895, 75 no. 9), published a year before Le Camus's book, but without mentioning its location. Weber had also published this particular inscription (Weber 1892) but, again, received no acknowledgement from Le Camus. However, Le Camus also noted that the inscription-with-relief lay temporarily at the village (not station) of Goncalı before being transferred to Smyrna. Weber's account of this Dionysios inscription makes no mention of Goncalı (station or village) because he is reliant on the Smyrna location, to which the stone with relief had been transferred, probably in 1889 or 1890. That is, the particular search for stones that yielded such prize examples was almost certainly related to the construction of the railway line, not to a touristic display. This means that Le Camus's 1896 publication depends in considerable detail not on autopsy but upon information gleaned from others.

${ }^{34}$ Le Camus makes a note of a fragment of an inscription "-HN $\Omega N$ " that he had found but this was his sole discovery (Le Camus 1896, 176).

${ }^{35}$ Le Camus 1899a, 861. The date of the Lycus Valley travels is noted by Thonemann $(2011,79)$ but not by Greenhalgh. 
Weber (with spare acknowledgement) ${ }^{36}$ and his own guide Hélias, whom he scorned as a "criminel". ${ }^{37}$

Georges Cousin did not provide any provenance for the inscription. However, Cousin included the Dionoisios inscription following an examination of another tomb inscription in which he considered he had a reference to the city of Sanaos, a site near to Appa station. Cousin did not make any connection between the two inscriptions nor connect the Dionoisios inscription with Sanaos. In fact, he sweepingly asserted, "La provenance de tous des restes antiques est inconnue.". ${ }^{38}$ And yet, precisely that connection has been made in the Lexicon of Greek Personal Names where the names in the inscription are listed according to Cousin's transcription, but given the provenance of Sanaos. ${ }^{39}$

Accordingly, we have three different locations given as the source of the inscription: Laodikeia, Colossae and Sanaos. No dimensions are given, no photograph or sketch appears to have been taken, ${ }^{40}$ and little sure detail provided about the particular type of tombstone. Of further complication is that a close comparison between the transcriptions reveals a number of differences in the reading. There is no indication that any of the copyists made a squeeze of the inscription. Rather, it seems that each person made an autopsy copy in his notebook. ${ }^{41}$ The following set of parallels (fig. 3) provides the inscription, firstly in the print-version of the transcription of what was seen on the stone (by Weber and Cousin) and secondly, in the reconstruction offered by the three.

\begin{tabular}{|c|c|c|}
\hline \multicolumn{2}{|c|}{ Weber 1893 (1892?) - A } & Cousin 1904 (1898) - B \\
\hline & TOMNHM & TOMNHMEION \\
\hline \multicolumn{3}{|c|}{$\triangle I O N O I C I O Y A$} \\
\hline & $\Gamma E \wedge I K O Y K A I T$ & AIONOICIOYAI \\
\hline & $H \sqsubset \Gamma Y N A \mid K O \sqsubset$ & ГЕ $\Lambda$ IKOYKAI'T \\
\hline 5 & AYTOYTATA & HETYNAIKOE \\
\hline & $K A \mid T H \sqsubset \odot Y$ & AYTOYTATA $[\Sigma$ \\
\hline & $T P O \sqsubset H M \Omega N$ & 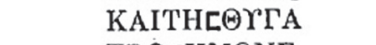 \\
\hline & IPHNHᄃ.EN $\Omega$ & TPOEHMQNE \\
\hline & ETEPOᄃOYK & IPHNHᄃENQ \\
\hline 10 & $H \triangle E Y \odot E I$ & ETEPOEOXK \\
\hline & ETI $匚 T I N$ & $\mathrm{H} \Delta \mathrm{Er} \Theta \mathrm{H} \mathrm{cI}$ \\
\hline & $K H \triangle E Y$ & ETILETEPOC \\
\hline & $\sqsubset E|T \Omega \phi| \subset K \Omega$ & K H $\Delta \mathrm{E} \Upsilon \mathrm{CETAI}$ \\
\hline & * & ᄃEITQ $\Phi$ I ᄃK $Q$ \\
\hline
\end{tabular}

Fig. 3) Reproductions of the published transcriptions of the inscription at Appa Station on the Ottoman Railway line

\footnotetext{
${ }^{36}$ Weber is mentioned as providing directions for Le Camus's brief trip to Ephesus (Le Camus 1899b, 342). This is the only reference to Weber in his published writings that I have found.

${ }^{37}$ Le Camus 1896, 196.

${ }^{38}$ Cousin 1904, 232.

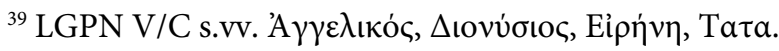

${ }^{40}$ This is in striking contrast with Weber's 1892 publication which included a fine-quality photograph (not his own) of the Dionysios' relief-epitaph then held in the garden of the Imperial School at İmir.

${ }^{41}$ Ramsay refers to his "copy" in a footnote. The meaning of "copy" is explained in a subsequent footnote when he refers to M. Clerc's "copy" of another inscription and adds "He leaves a blank in transcribing." (Ramsay 1897, 542, nos. 2, 3).
} 
The published transcriptions are somewhat stylized, as probably demanded by editorial requirements. However, some elements can be derived:

i) both agree that the inscription contains 14 lines of text;

ii) both appear to agree that a three-hastae sigma is used in the inscription; this is reinforced by the use of a four-bar sigma in Cousin's only supply of a missing letter in 1. 5;

iii) Cousin's transcription is more complete than Weber's, seemingly with only one abraded letter to be supplied (1.5) compared with seven lines containing letters unable to be read by Weber (11. 1, 2, 5, 6, 10, 11, 12);

iv) Cousin signals a gap between 1.1 and 1.2 of the inscription - not given by Weber;

v) Cousin appears to signal adjustments in the left margin of the inscription in 11. 12, 13;

vi) there is a small discrepancy in the letters on lines where both copyists read characters; so, in 1.11 Weber read ETICTIN whereas Cousin read ETICETE...;

vii) the text, even without reconstruction, clearly indicates an epitaph.

When we come to the discrete, reconstructed text, we are able to add Ramsay's copy to those of Weber and Cousin.

\section{Weber 1893}

1 Tò $\mu \nu \eta \mu[\varepsilon \tilde{c} \mathrm{ov}$

$2 \Delta$ เovoเóov $\mathrm{A}\left[\gamma^{-}\right.$

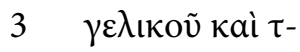

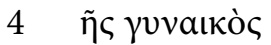

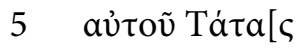

6 кaì $\tau \tilde{\eta} \varsigma \theta v[\gamma \alpha-$

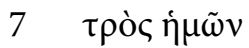

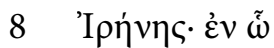

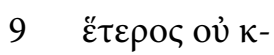

$10 \eta \delta \delta \varepsilon \dot{v}(\sigma) \varepsilon \iota[\varepsilon \dot{l} \delta$ -

$11 \dot{\varepsilon}$ тí $\operatorname{\tau iv}[a$

$12 \kappa \eta \delta \varepsilon \dot{ }[\sigma \eta, \delta \dot{\omega}-$

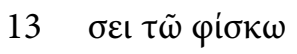

$14 \quad \mathrm{X} a$

\section{Ramsay 1897}

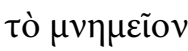

$\Delta$ tovolóiov

$\sum \varepsilon \lambda[\varepsilon \dot{v} ?]$ kov kaì $\tau$

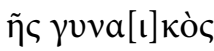

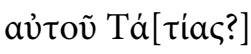

кaì $\tau \tilde{\eta} \varsigma \theta v \gamma \alpha]^{*}$

$\tau \rho \grave{\varsigma} \dot{\eta} \mu \tilde{\omega} v$

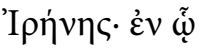

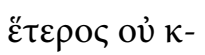

$\eta \delta \varepsilon v \theta \eta \dot{\sigma} \sigma[\varepsilon \tau \alpha \cdot \cdot \varepsilon i$ i $\delta-$

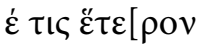

$\kappa \eta \delta \varepsilon \dot{\sigma} \sigma[\varepsilon \iota, \delta \dot{\omega}$

$\sigma \varepsilon \iota \tau \tilde{\omega} \hat{i}[\varepsilon \rho \tilde{\omega} \varphi \dot{i} \sigma \kappa \omega \underline{\omega}]$

$\delta \eta v ., a$

\section{Cousin 1904}

Tò $\mu \nu \eta \mu \varepsilon \tilde{o} \vee$

$\Delta$ tovoroíov 'A $\gamma$ - $\quad 2$

$\gamma \varepsilon \lambda$ เкой кaì $\tau-$

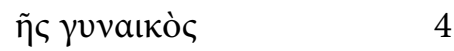

aủนoṽ Tá

кaì тп̃

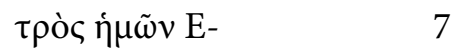

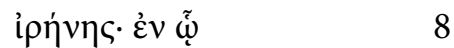

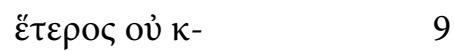

$\eta \delta \varepsilon v \theta \dot{\sigma} \sigma[\varepsilon l] ?$

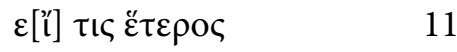

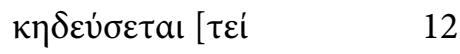

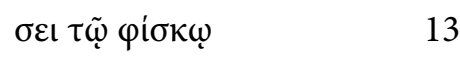

$\mathrm{X} \alpha^{-} \quad 14$

* Ramsay adds a square bracket here where he clearly intends a line break (|), as also at the end of 1. 13; he also omits line breaks at 1l. 11-12, thus turning a 14 line inscription into one of 11 lines. Here the breaks are supplied for the sake of comparison between the three reconstructions.

The lines which have complete agreement across the three are 1l. 1, 4, 6, 8 (excluding Cousin's addition of an epsilon at the end of 1.7), 9 and 14 (allowing for Ramsay's expansion of the meaning of X). Disputed readings occur in eight lines. At the very least, it points to the common complaint of epigraphers in the nineteenth century, that pristine readings were dependent not only on the condition of the stone but also on the season, the time of day and the level of light and shadow. 


\section{The Woman with a Camera}

Gertrude Bell's fascination with Asia Minor was fired by reading Strzygowski on Bin Bir Kilisse. ${ }^{42}$ She resolved to make her way to the country and see the array of architecture and remains of buildings that stemmed from an expansive Byzantine past. Bin Bir Kilisse was to give its name to a book that she co-wrote with Sir William Ramsay: The Thousand and One Churches. ${ }^{43}$ She had invited Ramsay to join her in the project; the breakdown of the work saw her take responsibility for the architectural analysis while Ramsay concentrated on the inscriptions. The decision came none too soon. The research - photographs, notes, measurements, locations, descriptions - was substantially conducted in 1907, with some revisiting of sites in 1909. Ramsay noted in the preface of the book that the gap of two years had meant a "melancholy difference" in the state of the sites, even as Hamilton's visit in 1836 described features no longer extant. "44 "Already much of the work which we did in 1907 has become the record of a vanished past; and therein lies its value.". ${ }^{45}$ The decision to fill the book with so many photographs was largely designed to compensate for the loss of so much material in the period between 1907 and 1909. ${ }^{46}$ Gertrude Bell was the main photographer for the expedition. Many of her photographs served the book; many more simply became the stockpile of records of now lost materials. They have fortunately been made accessible to wider research through the Gertrude Bell Project of the University of Newcastle. ${ }^{47}$ Bell's letters, extensive diary notes and photographs are held in this online resource. Her field notebooks for 1907 are held by the Royal Geographic Society in London. It appears that her focus was the churches of Bin Bir Kilisse, for there is nothing in the notebooks that relates to the journey and the stops she made in the Maeander Valley. Only her diary, letters and photographs retain a record of this earlier part of her travels.

Bell met up with Ramsay in May 1907 in Madensheher; ${ }^{48}$ her specific brief was to deal with architecture, ${ }^{49}$ but her insatiable drive covered far more. Prior to the commencement of the formal project, she travelled east from Smyrna through Apamea to Kara Dagh and Karaja Dagh on the Anatolian plateau before descending again to Konya. ${ }^{50}$ Ramsay accompanied her on the first section of her journey in "substitute" form - as she read sections of his writings, and followed up his epistolary requests and directives about places, roads, inscriptions to guide her movements. ${ }^{51}$

\footnotetext{
${ }^{42}$ Strzygowski 1903, 1-27.

${ }^{43}$ Ramsay - Bell 1909. The book was dedicated to Strzygowski.

${ }^{44}$ Ramsay - Bell 1909, vii.

${ }^{45}$ Ramsay - Bell 1909, 8.

${ }^{46}$ In fact, the losses in the previous twenty years had been vast (Jackson 2017, 51).

${ }^{47}$ Website: http://www.gerty.ncl.ac.uk. I am grateful to the University of Newcastle for permission to make use of fragments of this reservoir of invaluable material for this essay and particularly to Dr James G. Crow for his assistance in tracking down some of the Gertrude Bell information related to Colossae. Thanks are also due to the librarians of the Royal Geographic Society for their assistance with Gertrude Bell's field notebooks.

${ }^{48}$ Letter to her (step-)mother 25/5/07.

${ }^{49}$ Ramsay 1909, 39.

${ }^{50}$ Howell 2015, 116, 135-137.

${ }^{51}$ Diary entry 24/4/07; Letters 1/5/07, 4/5/07.
} 
The opening of her second contribution to the book (Part III) - the remarkable shift for the traveller when leaving the seaboard of Asia Minor for the central plateau ${ }^{52}$ - was the generalised expression of her own experience in April 1907. She compressed a huge volume of travel, exploration, photographing and writing into her days, even remarking that her energetic practice was not quite the pattern adopted by Ramsay. ${ }^{53}$ She also at times executed squeezes (which she called "rubbings"), ${ }^{54}$ some of which were later identified by William Calder in a batch given to him in 1922 by Ramsay. ${ }^{55}$

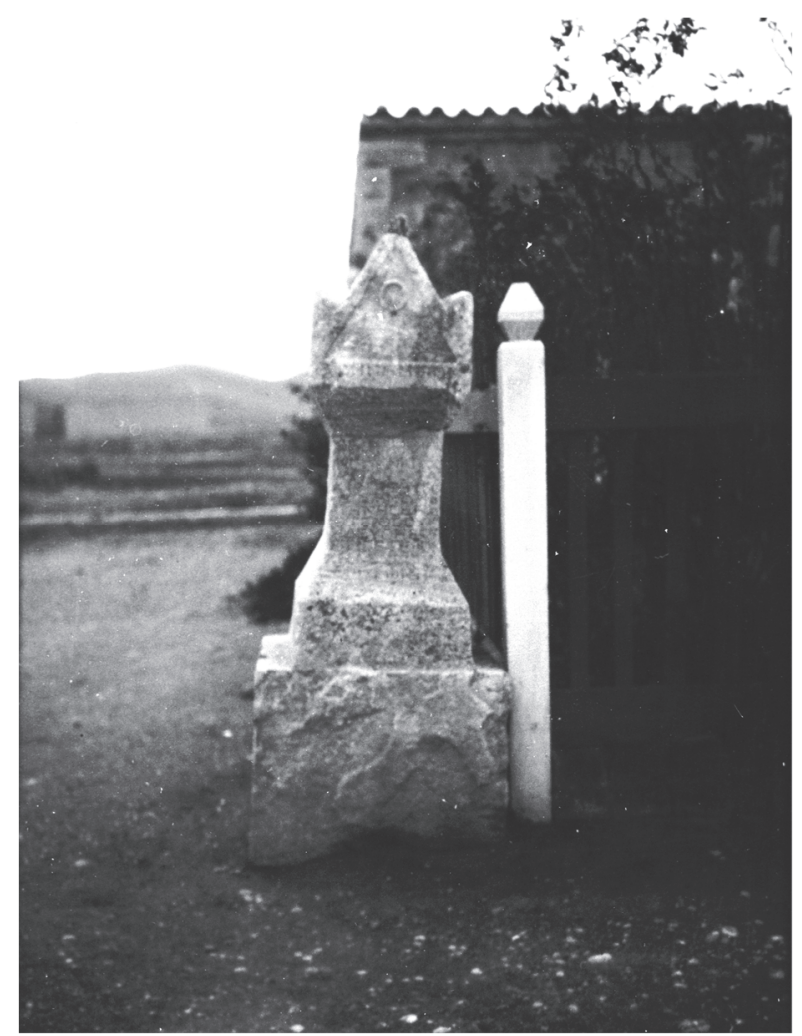

Fig. 4) Gertrude Bell's photograph of the "curious tombstone from Colossae"

In the course of her journey through the Maeander Valley, Bell visited Laodikeia and Hierapolis (Aphrodisias was included as well), ${ }^{57}$ and expressed the hope of adding Colossae to her itinerary, the completion of the Lycus Valley triangle. She decided to stay overnight in her railway carriage at Bodcelı so she could make an early start to Colossae the next day. ${ }^{58}$ Her hopes were dashed by sickness, however, that left her weak and faint: "But quite unable to go to Colossae which I gave up with much regret." The most she saw of Colossae was the view from the train of the magnificent setting dominated by Honaz Dağ (Mt Cadmus). The stop at the station at "Apa" (sic), on her way to "Dineir" provided a small compensation, for she found "A curious tombstone from Colossae there." 59 She writes generally in her letters of making contact with numerous railway and other officials, both high- and low-ranking on her journeys, insatiable for information. ${ }^{60}$ There appears little doubt that such is the source of her confidence about the provenance of the "curious tombstone". Nothing more is mentioned in her

${ }^{52}$ Ramsay - Bell 1909, 297.

${ }^{53}$ Letter to her (step-)mother 29/5/07.

${ }^{54}$ Diary entry $3 / 5 / 07$; letter $1 / 5 / 07$.

55 “Calder Collection" Ms 3286/10/17 Aberdeen Special Library. I am grateful to the librarians at the Special Library at the University of Aberdeen for permission to research the extensive Calder archive.

56 "Gertrude Bell Archive" Photograph F 210; reproduction by permission of the University of Newcastle-on-Tyne.

${ }^{57}$ Diary entries 22/4/07, 23/4/1907, 24/4/1907.

58 "I am sleeping in my carriage in order to see Colossae tomorrow morning." Letter to her (step-)mother 24/4/1907.

${ }^{59}$ Diary entry 25/4/07.

${ }^{60}$ Diary entries 25/4/1907, 10/5/07; letters 18/5/05; 11/5/1907. 
diary or in her letters. But she did take a photograph (fig. 4). It is the photograph that attracts great interest, for it provides some resolution and additional information on the inscription first published in 1893 by Weber and identified then, as in 1907, as coming from Colossae.

The discovery of a photograph of the tombstone itself is therefore of considerable value for the following reasons:

i) The stone is still shown to be in existence in 1907 at the Appa station.

ii) The provenance of the stone has not changed between the time of Weber's publication and Bell's photograph. There is no question for her that it came from Colossae.

iii) The photograph provides an opportunity to embed the inscription in its stone, by giving us the shape and features of the stone and the execution of the inscription in relation to it.

iv) The photograph provides an opportunity to check the various transcriptions and reconstructions.

v) This enables a new reconstruction to be given.

vi) The contribution invites further analysis of the inscription.

I shall take these elements as the basis for more detailed comments.

\section{i) The stone at Appa railway station}

The photograph shows that for at least fifteen years the stone was visible to train travellers on the Ottoman Railway line between Ephesus and Apameia. It appears to be placed outside the entrance to the station master's residence, though it may be another building connected with the station a residence tended to be part of a conjoined complex at stations along the Smyrna-Aidin line. Presumably by the time of William Calder's expeditions in 1933 and 1934, the stone had disappeared for it is merely noted in a list of additional inscriptions that had been published previously (ie Ramsay's edition) but not accessed by Calder. Accordingly, though not published by Bell, the photograph falls under the providence of the technological advance of the camera. In the face of the severe evaporation of stones and monuments in a short space of time, Ramsay had recognised how important photographs had become for many of the artefacts included in his 1909 publication with her. Crucially, this was at a time when communication and collaboration between Ramsay and Bell were at their height. No correction by Ramsay of Bell's note about provenance is to be found, even though she frequently records her discussions with Ramsay in her diaries and letters. It may, of course, have been subsumed by their more pressing project.

\section{ii) A bomos from Colossae}

Weber in 1893 and Bell in 1907 agree on the stone's provenance. Ramsay, whose transcription seems to be the one executed more hastily than the others, alone assigns it to Laodikeia. This may have been no more than a deduction from the general knowledge that Laodikeia had been extensively raided for "ballast" for the railway's construction. Although he did know the chief engineer of the railway, Joseph Walker, his generic phrasing "from the engineers of the Ottoman Railway" seems to indicate an unspecified understanding more than the result of a direct inquiry. Cousin's Sanaos inscription came from a höyük, which he gives as north of the village of "Sari- 
Khavak" (modern Sarıkavak) ${ }^{61}$ He expressly separates this Sanaos stone from others at the station by a reasonable walk of about an hour and a half. He neither ties the station's inscriptions to the site nor indicates any inquiry as to their source. He makes no mention of Weber's transcriptions, even though, within a paragraph, he clearly relies on his work. The weight of probability therefore favours Colossae as the origin of the stone. Corroborating this assignment, though not providing independent proof, is that the funerary bomos is designated tò $\mu \nu \eta \mu \varepsilon i ̃ o v$. This is consistently used in almost all extant Colossian funerary inscriptions. ${ }^{62}$ Of course, that designation is found on epitaphs from a number of places, even if it is allowed that there appear to be fashions in particular regions, if not cities, in particular periods. There are few inscriptions from Sanaos, even fewer epitaphs. However, one epitaph does use the term, though there is doubt whether it belongs to Sanaos. ${ }^{63}$ Two others, more assuredly connected with Sanaos, use $\dot{\eta}$ бopó $\varsigma$ as the designation of the funerary stone. ${ }^{64}$ This term, if found in Bell's photograph, would have seriously questioned her assignment to Colossae. Conversely, the use of $\tau$ ò $\mu \nu \eta \mu \varepsilon \tilde{o}$ v fits with the greater number of examples we have from Colossae.

\section{iii) The photograph adds a considerable amount of information}

The stone is commonly designated a funerary bomos, probably made of limestone. It has a general design that is still familiar from bomoi in various states of survival at the necropolis at Colossae. The following are examples, the first two containing inscriptions that have been previously published ${ }^{65}$ and each in decreasingly intact condition.

The Appa station bomos and its foundation are carved from a single stone, which has suffered only small amounts of damage to its base and the loss of the left matching triangular feature dropping from each end of the architrave of the pediment at the top of the bomos. The pediment itself is closer to an equilateral triangle, the plain acroteria are still in good condition, and a boss is positioned high in the apex of the tympanum (compare fig. $5 \mathrm{~d}$ ).

Only the photograph can communicate any sense of dimensions, stone and the like. The fence line affords a general impression of the height and width of the stone, sufficient to show that the dimensions probably cohere with the standard bomoi of the necropolis from Colossae, namely with a height of 1.3 to $1.45 \mathrm{~m}$., a shaft of $0.4-0.45 \mathrm{~m}$. wide and deep, and a base of $0.6 \mathrm{~m}^{2}$. A second, slightly taller bomos, now adorning a café near the ancient site but sourced from the necropolis, measures $1.65 \mathrm{~m}$. high, $0.84 \mathrm{~m}$. at the plinth, $0.60 \mathrm{~m}$. at the base of the shaft and $0.40 \mathrm{~m}$. for the width

\footnotetext{
${ }^{61}$ He may have meant "south" here; compare Anderson 1898, 90-91 where the necropolis location is given as south of the village.

${ }^{62}$ Cadwallader 2016, 184-187. Funerary inscriptions at Colossae that lack this term do not provide an alternative word, doubtless relying on the inscription itself, the form of the stone, and the location to convey the sense.
}

${ }^{63}$ SEG 28.1150 = IGRR IV.763. Ramsay thought it came from the countryside around Sanaos (Ramsay 1895, 232 no. 75): However, Thomas Drew-Bear connected it to Apameia (Drew-Bear 1978, 105-6 no. 43). Two other inscriptions given by Anderson restore the term in his reconstruction, with no warrant from the surviving letters of the inscriptions (Anderson 1897, 414-5, nos. 15, 16). Significantly however, fines for interference with these tombs at Sanaos are to be paid in Attic drachmas, not denarii.

\footnotetext{
${ }^{64}$ Anderson 1898, 91-92, nos. 28, 30. A further epitaph contains no designation (no. 29).

${ }^{65}$ Cadwallader 2007.
} 
of the shaft itself. This bomos is very worn but still contains a boss in the pediment and, on the shaft, two figures wearing short chitons and, perhaps, grasping an object between them with left and right hand respectively, or simply holding hands. Strikingly, this is very close to the description of one of the tombstones given by Georg Weber in 1891 (1890): "Auf einem andern Stein findet sich ein Relief, zwei einander gegenüber stehende Personen, die ihre Hände auf einen zwischen ihnen stehenden Gegenstand zu legen scheinen.”. ${ }^{66}$

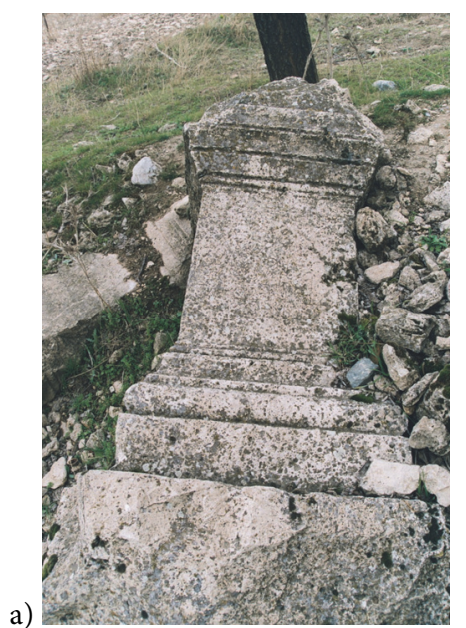

b)

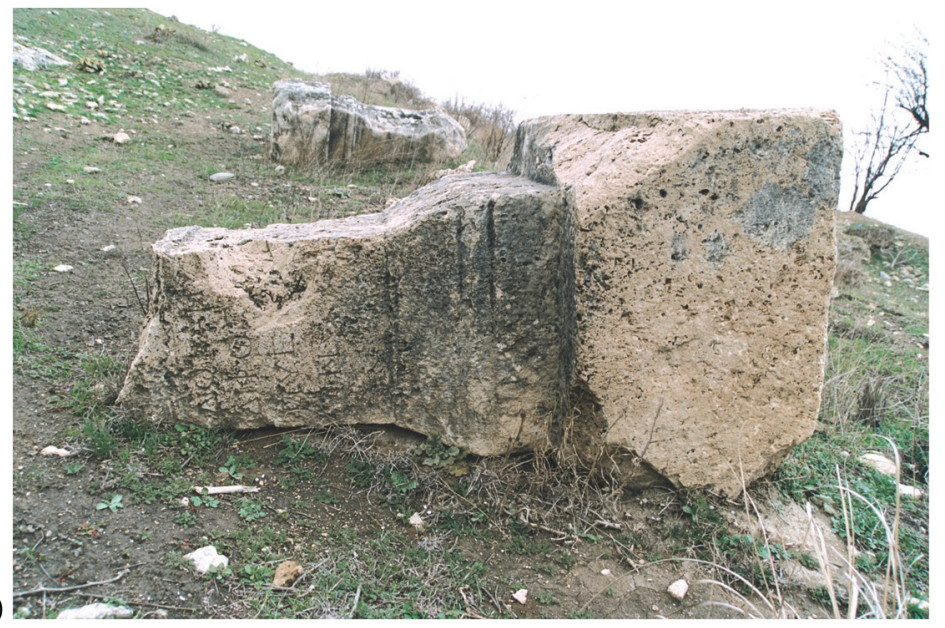

c)

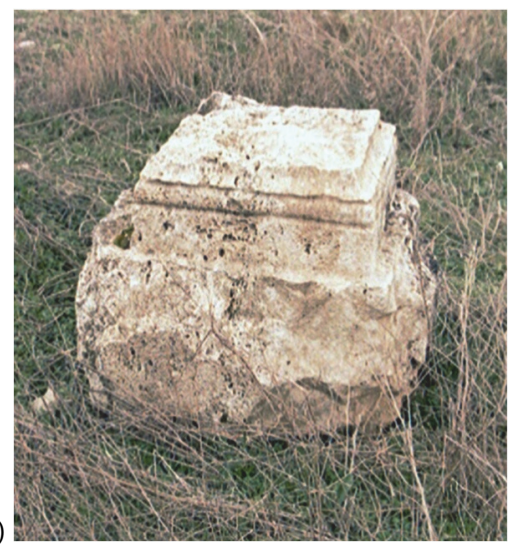

d)

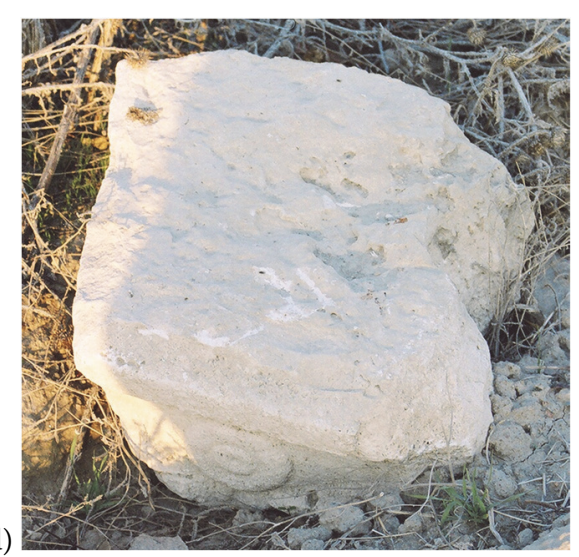

Fig. 5) Examples of funerary bomoi, located along the eastern rim of the necropolis basin at Colossae

Of course, there is no way of knowing if this very stone was the bomos Weber saw and briefly described; but it does indicate that this variety of bomos with relief at one time was visible in the necropolis at Colossae. Today, the extant bomoi in situ are almost all aniconic with only one or two containing the worn features of a symbol on the side of the shaft. ${ }^{67}$ But rather than Colossae's funerary bomoi being "singular," as Léon de Laborde had described them, ${ }^{68}$ the typology is attested at a number of sites in Phrygia, including Eumeneia and Laodikeia. ${ }^{69}$ Although Sanaos reveals similar pit-tombs or in-ground sarcophagi which are covered with large slabs, some of which are still extant at the Colossae necropolis ${ }^{70}$ there is no requirement that a funerary bomos weigh down

\footnotetext{
${ }^{66}$ Weber 1891, 198.

${ }^{67}$ Şimşek 2002; Cadwalader 2015, 155-179.

${ }^{68}$ Laborde 1838, 102.

${ }^{69}$ Duman 2008, 51-53.

${ }^{70}$ Cadwallader 2015, 156-158.
} 
the slabs (as well as mark and record the grave). A pedestal epitaph, such as recovered by Bahadır Duman in his Sanaos survey, functions equally well. ${ }^{71}$ The early gathering of transcriptions by J. G. C. Anderson, always limited in his descriptions of the stones, suggests that funerary inscriptions may even have been carved on the cover slabs themselves. ${ }^{72}$ At the same time, reliance on design alone cannot decide for Colossae as the source. Colossae cannot claim the sole instances of shape, but its stonemasons certainly favoured the style. Again, there is nothing in the form to disprove the at least fifteen-year connection, from Weber to Bell, of the Appa station bomos with Colossae.

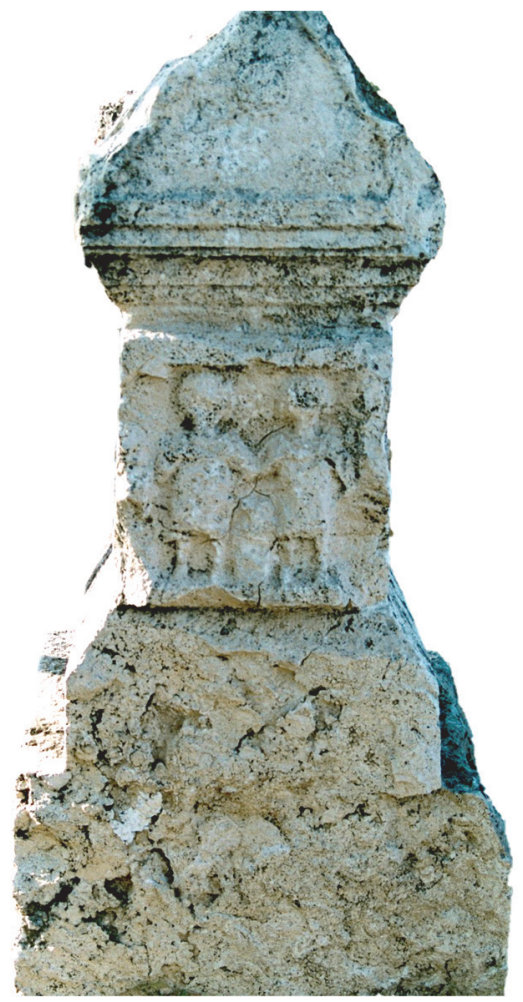

Fig. 6) A bomos with relief originally from the necropolis at Colossae

\section{iv) Inscribing the stone.}

Gertrude Bell's snap-shot lacks the sharpness and compression of today's photography. However, by combination of computer magnification and enhancement, ${ }^{73}$ and constant cross-checking with the three transcriptions, the inscription is able to be restored, especially in its arrangement on the stone and its letter shapes. It confirms that the photograph is, in fact, of the stone seen by Weber, Ramsay and Cousin at Appa station. The following sections of the bomos highlighting the inscription provide, firstly, a general magnification and sharpening of the photograph (fig. 7a) and secondly, an enhancement of contrast using Photoshop software (fig. 7b). A further clarification will follow in the next section.

\footnotetext{
${ }^{71}$ Duman 2008, 53, pl. 25 [corr.].

${ }^{72}$ Anderson 1898, 91 no. 28.

${ }^{73}$ For technical assistance in this regard, I am grateful to my son, Daniel Cadwallader.
} 

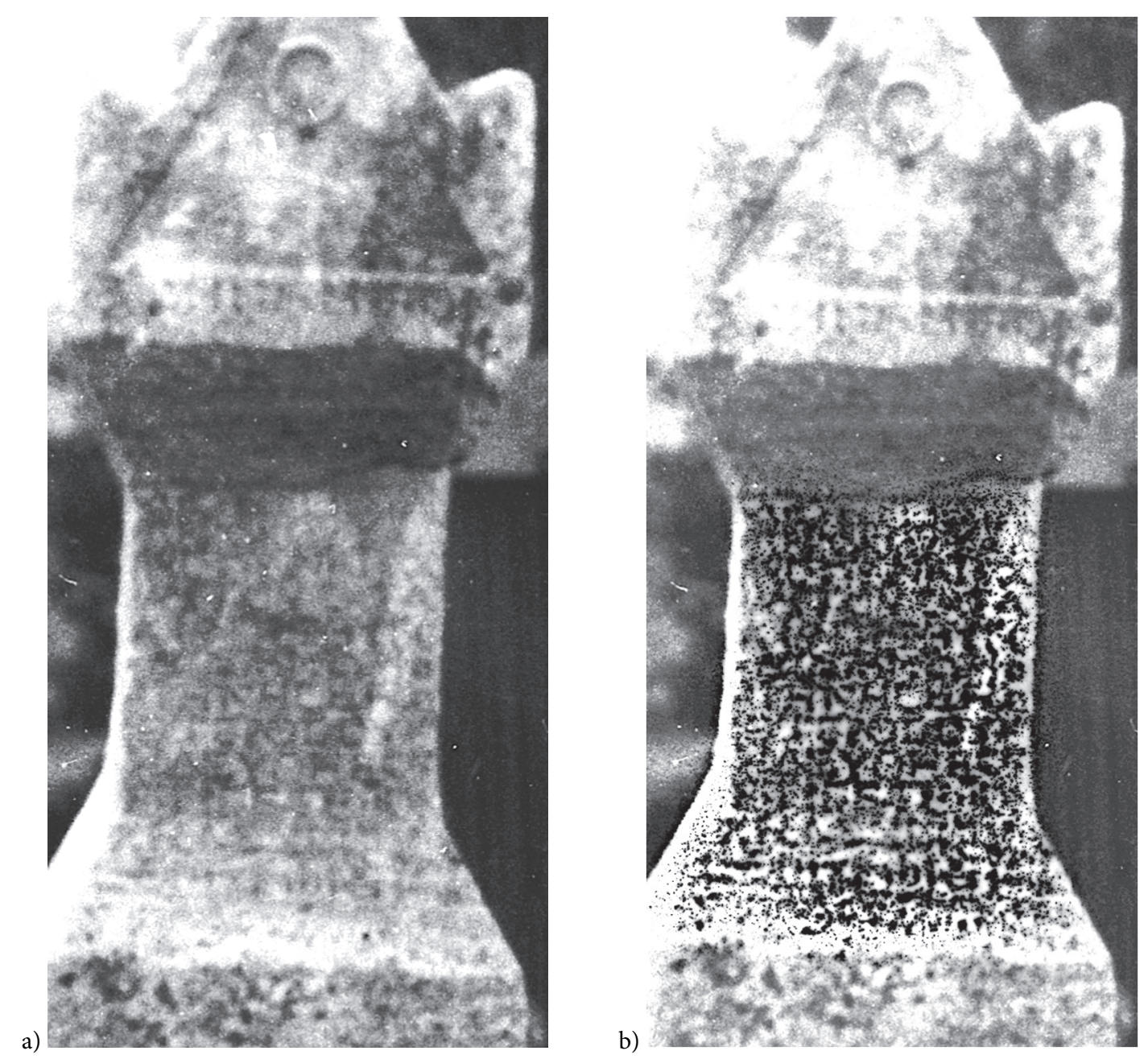

Fig. 7) Enhancement of Bell's photograph of the inscription on the Appa station bomos.

The photograph confirms Cousin's indication through his arrangement of the text of the inscription that the opening designation, $\tau$ ò $\mu \nu \eta \mu \varepsilon \tilde{o} v$, was carved on a segment of stone separate from the rest of the inscription, which begins below the simple, profiled molding introducing the shaft. "The tomb" was carved on the horizontal architrave of the pediment of the bomos. The tau seems to have been partially lost in slight damage to the lower left of the pediment. Given that the three copyists had no difficulty reading the tau, the damage probably occurred after 1898 , the year Cousin saw the stone. Cousin is also accurate in his alignment of the margin of the inscription at 11. 12-13. These lines are carved onto the bevelled moulding concluding the shaft. However, this does not appear to have allowed much extra space for letters, especially given that the omegas and the phi are carved with large curvilinear incision (see further below). Consequently, it is difficult to accept Ramsay's fourteen letters for 1.13 and certainly for 1 . 10. The number of letters per line seems confined to 9-12. (Accordingly, Ramsay's sacred treasury can no longer be sustained.) However, the eight letters for 1.7 (in Weber and Ramsay's copies) invites a search for an epsilon at the end of the line, to begin the genitive Eipñvฺ. The lettering itself is simply executed with little or no evidence of serifs (1.14 may be an exception), no ligatures or cross-bars on the upsilons and, apart from the final line and in small measure the first line, using the full width of the stone. The squared sigma, seemingly consciously shaped by the three copyists in their publications, is confirmed as using three hastae. The omega is lunate with simple filials and the theta has a short 
cross-bar. The alpha has a straight cross-bar. The diagonals of the $m u$ are shortened to mid-height above the horizontal. These observations may contribute some evidence to the question of date.

\section{v) A new reconstruction of the text.}

Although the value of the photograph needs to be treated cautiously in the effort to provide a new reading of the inscription, it is possible, in combination with a critical analysis of the three copies and constant reference to computer magnification, to reach a greater confidence about the text of the inscription.

a)
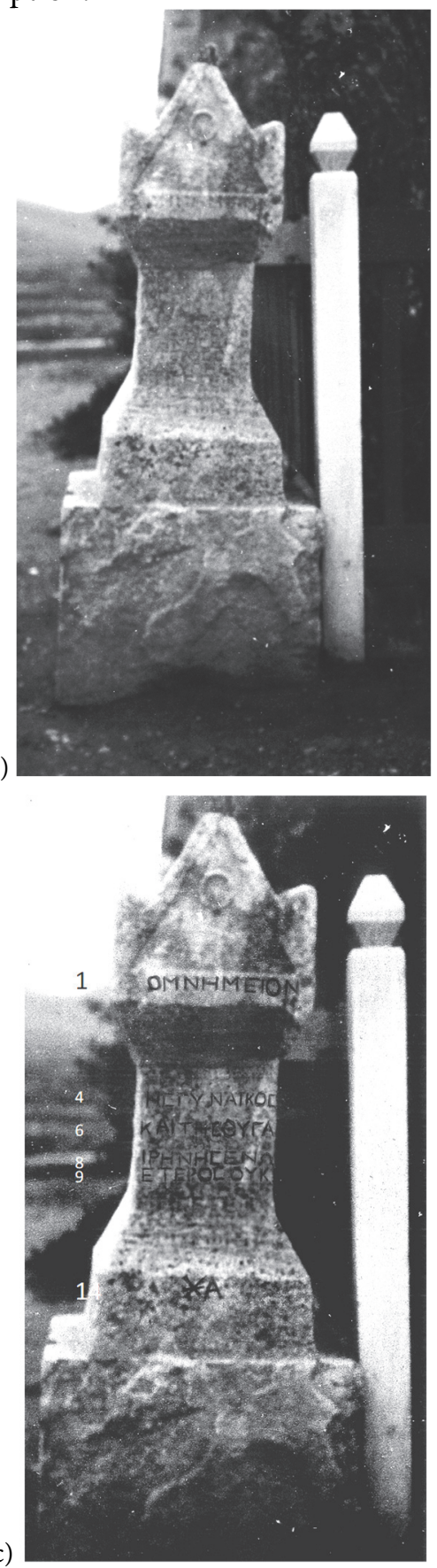

b)
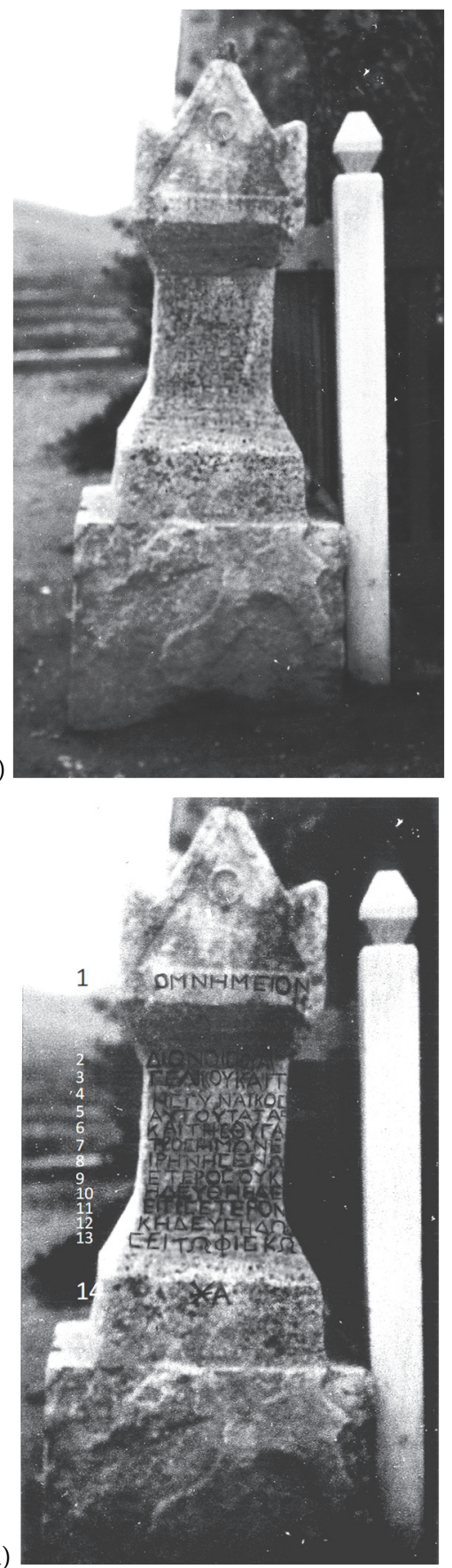

Fig. 8) Reconstruction of the wording of the inscription

In order to demonstrate, I supply Bell's surviving photograph (fig. 8a), a repeat general enhancement of the inscription (fig. 8b), then add those lines that all three copyists agreed upon (ll. 1, 4, 
$6,8,9,14$ ), by highlight on the inscribed section of stone (fig. 8c). This will enable greater confidence in recognizing letters on those lines where there is disagreement among the copyists (fig. 8d). This exercise has enabled reasonable confidence in establishing the text as follows:

$$
\begin{aligned}
& \tau] \text { ò } \mu \nu \eta \mu \varepsilon \tilde{o} v \\
& \text { vacat } \\
& \Delta \text { เovoroíov 'A } \gamma \text { - }
\end{aligned}
$$

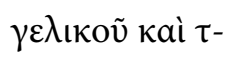

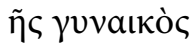

$$
\begin{aligned}
& 5 \text { av่นoṽ Táta }
\end{aligned}
$$

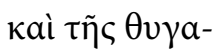

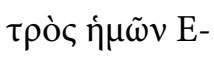

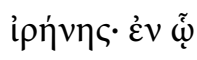

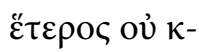

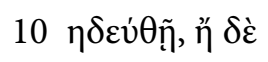

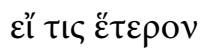

$$
\begin{aligned}
& \kappa \eta \delta \varepsilon v \dot{\sigma}\rceil, \delta \dot{\omega}-
\end{aligned}
$$

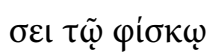

$$
\begin{aligned}
& \text { vacat } \\
& \mathrm{X} a
\end{aligned}
$$

Translation: (This is) the grave of Dionysios son of Aggelikos, and of his wife Tata, and of his daughter Eirene. In it, another is not to be interred; or, if someone should bury another (in it), he will pay to the treasury 1000 denarii.

On my restoration of the inscription from Gertrude Bell's photograph, in dialogue with the three copyists, I have found no reason to doubt the lines on which they are all agreed (that is, 1l. 1, 4, 6, $8,9,14)$. The final line stating the fine for infraction of the sanctity of the tomb (1000 denarii, 1.14), appears at the top of the base just below the bevelled edge. This gap, akin to the gap between 1.1 and 1.2, is not noted by any of the copyists. The oblique diagonal in the final alpha of 1.6 is obscure (compare Weber's illegible final two letters) but the reading is secure. In the final line, I understand $\mathrm{A}$ as meaning, $\mathrm{A}$, in line with the three copyists published transcription, even though it is difficult clearly to discern the stroke.

It is possible to make some decisions about the reading of disputed lines.

At the end of 1.2 sufficient indications of both vertical and horizontal hastae for the gamma confirm the reading of the name, Aggelikos, by Weber and Cousin, against Ramsay. Ramsay had provided a footnote to his reconstructed $\Sigma \varepsilon \lambda[\varepsilon v$ ? $]$ Kov stating that he had CE $\Lambda$ IKOY in his copy, "which may be right". ${ }^{74}$ Given that the three copyists seem to be in agreement about the square shape of the sigma, the letter shape easily resembles the gamma registered by Weber and Cousin, thus strengthening the reading 'A $\gamma \gamma \varepsilon \lambda$ ıкóc.

In 1.5 , although the last alpha comes close to the end of the line, there is, following the alpha, a small, but fairly clear, upper horizontal hasta and, less clearly, a vertical stroke and lower

\footnotetext{
${ }^{74}$ Ramsay 1897, 542 n2.
} 
horizontal stroke. This suggests that a fairly common method of squeezing an extra letter to the line has been deployed - simply making it smaller and slightly raised (though a superscript mode is not always followed). ${ }^{75}$ The shape of the smaller sigma follows that of the standard sigmas in the inscription - that is, a square sigma made by one vertical stroke and two horizontal strokes parallel to each other.

In 1.7, an epsilon at the end of the line seems fairly clear, thus confirming Cousin's reading, against Weber and Ramsay. This removes the name from the rarer form, 'I $\rho \eta v \eta .{ }^{76}$ In any case, this spelling is known before Christian witness in inscriptions. ${ }^{77}$

Lines 9-10 seems to have provided considerable difficulty to the copyists, possibly because their familiarity with readings in other epitaphs yielded a commonly used formula. However, the aorist passive subjunctive form is attested at Hierapolis (AvH 55b) in the phrase $\dot{\varepsilon} v \tilde{\eta} \tilde{\kappa} \kappa \eta \delta \varepsilon v \theta \tilde{\eta}$ where the

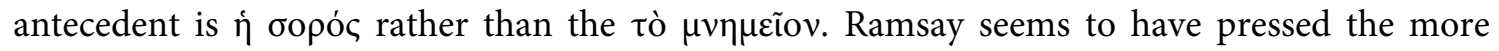
familiar future passive onto the text; and Weber, curiously, has gone against the reading of his copy. The photograph seems to suggest a second eta, which readily negates the sigma in Ramsay

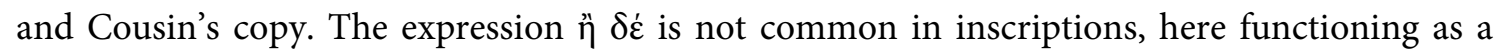
contrastive, but it is known. ${ }^{78}$ It is also possible to read it as a single word, $\eta \dot{\eta} \delta \dot{\varepsilon}$, in the sense of "and", though this is usually confined to poetic usage, occurring, inter alia, in metrical epitaphs. ${ }^{79}$ The epsilon at the end of 1.10 seems secure, even if the preceding delta is less obvious.

Lines 11-12 follow readily from the reading in 1.10. The iota of $\varepsilon$ i is reasonably clear, and secured

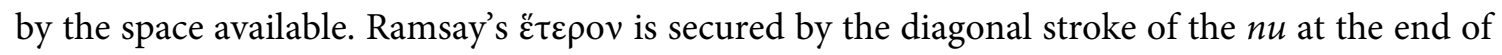
the line (against Cousin's sigma). This allows a sound reading of, probably, a future subjunctive form, $\kappa \eta \delta \varepsilon v$ бn (or alternatively an itacistic future indicative) in 1.12. The omega of $\delta \omega$ - seems sufficiently distinct to favour Weber and Ramsay over Cousin's reading.

${ }^{75}$ For a close parallel, see Malay - Tanriver 2016, 176, no. 2, 1.5. For other examples of similar letter compression, see MAMA VI.193, 1.5 (Apameia); MAMA XI.36B, 1.2 (Eumeneia); MAMA XI.121, 1.12 (Akmoneia); MAMA XI.136, 1l. 11, 12 (Pentapolis), SEG 57.1210, 1. 6 (Saittai); IG X.2.1s.1058, 1100, 1122 (Thessalonika). Compare I.Laodikeia Lykos 104, mentioned previously, where a small four-bar sigma is inscribed inside the larger omicron at the end of 1.4. The same feature is found in a Greek epitaph from just outside of Rome: IGUR III.1175, 1.4 (also with a small $n u$ inside an omega, 1.7; now displayed at the Cecilia Metella Mausoleum museum); from Samos: IG XII.6.1.425, 1.3 (also with an upsilon inside an omicron, 1.4); with a sigma inside a lozenge omicron see IG X.2.1.209, 1.7 (Thessalonika); for the latter see Daux 1976, 2167. The feature is noted by William Calder in his notebook (Calder Archive Ms 3286/4/ "1933 Notebook"p.44, \#173 but not in publication (for MAMA VI.43). Corsten also noted it (I.Laodikeia Lykos, 187). The breadth of provenances shows that this was a relatively common lithographic device. For an iota inside an omicron, see IG X.2.1s.1107 (Thessalonika); for an upsilon inside an omicron, see IG X.2.1s.1239.

${ }^{76}$ In the light of this detailed study of Bell's photograph, I need to correct the reading I adopted from Weber (Cadwallader 2016, 184-5).

${ }^{77}$ IG II'.8060, Attica; IG VII.1798, Thespiai; TAM II,3.959, Olympos.

${ }^{78}$ IGUR II.463 (Rome); IG II.11169 (Attica); Peek, GVI 1.738 (Hermoupolis Magna). Compare the regulations of a funerary foundation from Tlos: SEG 58.1640C at l.17.

${ }^{79}$ See SEG 35.1233 (Saittai area, 148/9 CE); SEG 36.1165 (Herakleia); MAMA X.137 (Appia area, $3^{\text {rd }}$ century $\mathrm{CE}$ ). 
As mentioned earlier, Ramsay's inclusion of iع $\rho \tilde{\omega}$ in 1.13 is unsustainable given space for the usual number of letters per line. The photograph confirms Weber and Cousin's reading.

\section{vi) Some reflections on the inscription.}

A detailed investigation of a relatively standard funerary inscription is not usually warranted. However, apart from the general pursuit of accuracy in text and provenance, there is an onomastic witness that is particularly pertinent for the study of the ancient site of Colossae. That name is Aggelikos, the father of the deceased. The name is quite rare, whether spelt with a double gamma or in the form nu-gamma. It is known in a mid-second century (CE) Greek inscription from Rome entered in a multi-columned list of Dionysian mystery-cult initiates (IGUR I.160.I.d, 1.29) ${ }^{80}$ It also has been found (in the form 'A $v \gamma \varepsilon \lambda$ เкó $\varsigma$ ) on a third-fourth century epitaph, provenance unknown, but located in the museum at Konya (I.Mus. Konya $158=$ SEG 58.1654). Related names,

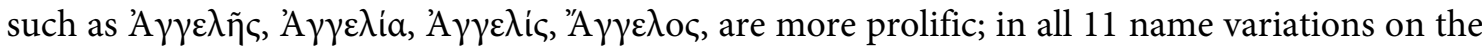
basic ä $\gamma \gamma \varepsilon \lambda$ oc, totalling 53 instances, are attested in the Lexicon of Greek Personal Names. ${ }^{81}$ Whilst still relatively rare, there is demonstrated a certain interest in naming a son or daughter by this particular divine namesake. Such an onomastic practice extends several centuries prior to this period. However, 'A $\gamma \gamma \varepsilon \lambda$ ıкó itself is particularly rare, compared, say, to 'A $\gamma \gamma \varepsilon \lambda \tilde{\eta} \varsigma$, which claims 25 of the 53 instances. It also is the only example of this theophoric association at Colossae.

The word occurs as a descriptor of Christian life..$^{82}$ But at Stratonikeia, it seems to be a title for a

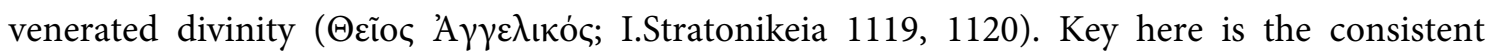
association of the word with the divine, whether a subordinate being or an independent deity. ${ }^{83}$ Gods such as Zeus, Mên or Hecate might send angels but may themselves be or act as angels, clearly indicating both the ability to interact with humanity and also to receive honour and devotion. Certainly it is no longer doubted that the worship of angels had a substantial preChristian history. ${ }^{84}$ On this basis, the onomastic evidence for 'A $\gamma \gamma \varepsilon \lambda$ ıкó be classified under theonyms, that is, names that are formed from the designation of a deity. There are many such names among the onomastics of Colossae - including another example, Dionysios, ${ }^{85}$ on this very stone - among which should be grouped Aggelikos. Indeed, it seems that a

\footnotetext{
${ }^{80}$ This instance is omitted in LGPN.

${ }^{81}$ No instance of the softened form ä $v \gamma \varepsilon \lambda$ - is onomastically attested, except in compound names such

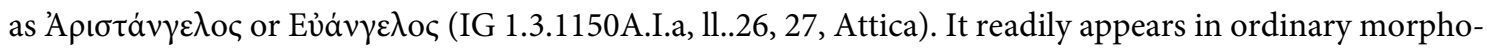
logical usage (eg IG 1.2.784 [Attica].

${ }^{82}$ SEG 27.207 (Larisa); CIG 8654 (Gerasa).

${ }^{83}$ The two options presented here have their own supporters. The former is favoured by Marijana Ricl and Stephen Mitchell (Mitchell 2013; Ricl 1992; Ricl 2008). The latter is the preferred option of Nicole Belayche (Belayche 2012). However, she does admit that angels may be "the divine power manifesting itself through various modalities." (Belayche 2010, 65).

${ }^{84}$ Horsley - Luxford 2016.

${ }^{85}$ See also I.Laodikeia Lykos 104 referred to above as probably from Colossae rather than Laodikeia. Compare BCH 11 (1887), 353 no. 10, a fragmentary inscription which has been taken, probably rightly, as honouring a priest of Dionysos (Quandt 1913, 216). Dionysos is also attested on coins of Colossae; see (von Aulock 1984, 84 no. 454). Further numismatic witness to the cult of Dionysos has surfaced since von Aulock's catalogue (Cadwallader 2021).
} 
preference for theonyms is quite marked in Anatolia. ${ }^{86}$ How much religiosity is intended by the choice of names is debated; however the rarity of the name moves the level beyond a "vague penchant". ${ }^{87}$

Given that names are about identity formation, even in a minimalist sense, a local association of the name is likely. Here, the early Christian witness is significant. The New Testament Letter to

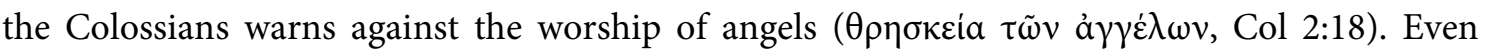
allowing that the letter is pseudepigraphic, it seems to imply that a cultic focus on angels was part of the religious backdrop at Colossae. A second, later witness is an early fifth-century Christian text, whose main character, Michael the archangel, is described in terms that have strong evocations of Zeus. ${ }^{88}$ The story itself seems, in substantial sections, to be a Christian re-working of a pre-Christian narrative (probably a foundation narrative associated with a sanctuary). ${ }^{89}$ This strongly suggests that there was a local cultural expression that was reflected in the name, Aggelikos. The connection of Colossae with angels gained the rebuke of at least one church father (Theodoret of Cyrrhus), in the fifth century. It seems the cultural commitment tenaciously held on in local Christian expression, albeit increasingly in receipt of overt Christian dress.

It is certain that this funerary bomos falls within the date range of these two pieces of writing, that is, between the first and fifth centuries CE. We can seek to make that more specific, by analysis of the various elements that point to a general date range, in the absence of specific calendrical reference. Those elements are letter formation, onomastics, the form of funerary monument and specific details, such as the level of the fine. In terms of letters, the combination of squared sigmas with other unembellished letters, including the absence of "serif envy", ${ }^{90}$ inclines us to a date in the first century, for this inscription. ${ }^{91}$ This determination might be off-set by the fine of 1000 denarii for disturbance of the tomb. Other funerary bomoi from Colossae, impose a fee of 500 denarii. ${ }^{92}$ Johan Strubbe considered that the higher amount might be an indicator of inflation in the Roman empire, especially in the second half of the third century.${ }^{93}$ However, the size of a tomb and/or claims upon status are also factors to be considered. ${ }^{94}$ There are currently too few epitaphs with desecration fines for meaningful comparison, so, at this stage, any observations must be very tentative. One funerary bomos prescribing a fine of 500 denarii can confidently be placed in the third century because of the (disordered) citizenship formula (IGRR 4.871). The names, Dionoisios (for Dionysios, a reverse of the common phonological change of -o to - $v$ ), Aggelikos and Eirene are all solid Greek names (whether aspirational or historic ethnicity), with Tata a common

\footnotetext{
${ }^{86}$ Colvin 2004, 58.

${ }^{87}$ Parker 2000, 62.

${ }^{88}$ Cadwallader 2012.

${ }^{89}$ Cadwallader 2018.

${ }^{90}$ Macrakis 1996, xx. It should be noted however that the presence of serifs does not necessarily imply a later period. Serifs are occasionally attested in Attic epigraphy two centuries before the common era (Tracy
} 1990).

${ }^{91}$ I.Mus. Burdur, 139-140 no. 225.

${ }^{92}$ IGRR IV.871; MAMA VI.43; AS 56, 2006, 103-11 at 108.

${ }^{93}$ Strubbe 1997, 74-78.

${ }^{94}$ Perhaps Dionoisios's bomos was of the larger size, noted above. 
Lallname, albeit of indigenous origin. There is no hint of Roman citizenship. Accordingly, a general date span of 50-150 CE is probably acceptable.

\section{Conclusion}

One small inscription in the vast inventory of Asia Minor epigraphy has gained considerable attention here. The text, provenance and stone of the inscription has remained quietly in dispute since three copyists, independently of each other, copied into their notebooks the reading they could make out on a display piece at Appa station on the İzmir-Dinar Ottoman railway line. It has been established that the most probable provenance of the piece is Colossae, confirmed by three witnesses (Georg Weber, Charles Wilson and Gertrude Bell) from 1893 to 1907 against a single, generic assertion of Laodikeia (William Ramsay) and an "unknown" (Georges Cousin). It definitely warrants a change from the provenance (Sanaos) given by LGPN V.c in the entries for the names Dionysios, Aggelikos, Tata and Eirene.

Unknown in the various reproductions of the hand copies, has been a photograph taken by Gertrude Bell in April 1907. This photograph demonstrates that the inscription was carved onto a funerary bomos, of a type well-attested at the necropolis at Colossae. Although the photograph is slightly blurred, it clearly reveals an inscription on the pediment and shaft of the bomos. The use of computer technology has enabled the inscription to be read accurately in toto for the first time. This has produced a text that consolidates some of the readings from each of the three copyists and offers a couple of new adjustments. No one copyist has been confirmed in all his readings, demonstrating that the process of copying in the nineteenth century was not without its pitfalls caused by bad light and pressure of time (to catch the departing train?). One particular name on the inscription has been found to offer some potential contribution to a long-standing, though variable, religious practice at Colossae (the worship of angels). ${ }^{95}$

\section{Bibliography}

Ainsworth 1844

W. F. Ainsworth, Travels in the Track of the Ten Thousand Greeks; being a Geographical and Descriptive Account of the Expedition of Cyrus and of the Retreat of the Ten Thousand Greeks as related by Xenophon, London 1844.

Anderson 1897

J. G. C. Anderson, Summer in Phrygia I, JHS 17, 1897, 396-424.

Anderson 1898

J. G. C. Anderson, A Summer in Phrygia II, JHS 18, 1898, 81-128, 340-344.

AvH C. Humann et al., Altertümer von Hierapolis, Berlin 1898.

Baedeker 1905

K. Baedeker, Konstantinopel und Kleinasien: Handbuch für Reisende, Leipzig 1905.

Beamont 1855

W. J. Beamont, Journal of a Visit to the Seven Churches of Asia, Warrington Library Museum and Archives Ms 706, 1855.

Belayche 2010

N. Belayche, Angeloi in Religious Practices of the Imperial Roman East, Henoch 32.1, 2010, 44-65.

${ }^{95}$ I am grateful to Professor Greg Horsley for his kindness in reading and offering many helpful comments on an earlier draft of this article. 
Belayche 2012

Bell 1907

Brennan 1999

Buckler - Calder 1939

Cadwallader 2007

Cadwallader 2008

Cadwallader 2012

Cadwallader 2015

Cadwallader 2016

Cadwallader 2018

Cadwallader 2021

Colvin 2004

Cousin 1904

Daux 1976

Drew-Bear 1978

Duman 2008
N. Belayche, Les dédicaces 'au divin ( $\tau \tilde{\omega} \Theta \varepsilon(\tilde{\omega})$ ' dans l'Anatolie impériale, in: M. de Souza - A. Peters-Custot - F.-X. Romanacce (eds.), Le sacré dans tous ses états. Catégories du vocabulaire religieux et sociétés, de l'Antiquité à nos jours, Saint-Étienne 2012, 181-194.

G. L. Bell, Syria: The Desert and the Sown, London 1907.

M. G. Brennan, The Travel Diary of Robert Bargrave, Levant Merchant 1647-1656, London 1999.

W. H. Buckler - W. M. Calder, Monuments and Documents from Phrygia and Caria (MAMA VI), Manchester 1939.

A. H. Cadwallader, Two New Inscriptions, a Correction and a Confirmed Sighting from Colossae, EpigrAnat 40, 2007, 109-118.

A. H. Cadwallader, The Reverend Doctor John Luke and the Churches of Chonai, GBRS 48/3, 2008, 319-338.

A. H. Cadwallader, St Michael of Chonai and the Tenacity of Paganism, in: D. Kim and S. Hathaway (eds.), Intercultural Transmission throughout the Medieval Mediterranean: 100-1600 CE, LondonNew York 2012, 37-59.

A. H. Cadwallader, Fragments of Colossae: Sifting through the Traces, Adelaide 2015.

A. H. Cadwallader, One Grave, Two Women, One Man: Complicating Family Life at Colossae, in: A. H. Cadwallader (ed.), Stones, Bones and the Sacred: Essays on Material Culture and Ancient Religion in Honor of Dennis E. Smith, Atlanta, GA 2016, 157-194.

A. H. Cadwallader, 'As if in a Vision of the Night ...' Authorising the Healing Spring of Chonai, in: B. Neil and E. Anagnostou-Laoutides (eds.), Dreams, Memory and Imagination in Byzantium, Leiden 2018, 265-92.

A. H. Cadwallader, Wealthy, widowed, astute and beneficent: Claudia Eugenetoriane and the second century revival of the Colossian mint, in: J. R. Harrison et al. (eds.), New Documents Illustrating the History of Early Christianity, Volume 12, Grand Rapids, MI 2021, forthcoming.

S. Colvin, Names in Hellenistic and Roman Lycia, in: S. Colvin (ed.), The Greco-Roman East: Politics, Culture, Society, Cambridge 2004, 44-84.

G. Cousin, Kyros le Jeune en Asie Mineure (Printemps 408-Juillet 401 avant Jésus-Christ), Nancy 1904.

G. Daux, Notes de lecture, BCH 100, 1976, 201-234.

T. Drew-Bear, Nouvelles Inscriptions de Phrygie, Zutphen 1978.

B. Duman, Anaua'nin (Sanaos) Lokalizasyonu Üzerine Düşünceler, Pamukkale Üniversitesi Sosyal Bilimler Enstitüsü Dergisi 1, 2008, 43-64. 
Emrys-Evans 1918

Greenhalgh 2012

Greenhalgh 2013

Greenhalgh 2019

Hawley 1918

Herring 2015

Hogarth et al. 1908

Horsley - Luxford 2016

Howell 2015

Jackson 2017

Joanne - Isambert 1881

Laborde 1838

Le Camus 1896

Le Camus 1899a

Le Camus 1899b

Legrande - Chamonard 1893

LGPN

Macrakis 1996

Malay - Tanrıver 2016
D. Emrys-Evans, Notes on the Consonants in the Greek of Asia Minor, CQ 12, 1918, 162-170.

M. Greenhalgh, Constantinople to Córdoba: Dismantling Ancient Architecture in the East, North Africa and Islamic Spain, Leiden 2012.

M. Greenhalgh, The Demands of Modernity: Filching the Building Blocks of the Ancient World, Leiden 2013.

M. Greenhalgh, Plundered Empire: Acquiring Antiquities from Ottoman Lands, Leiden 2019.

W. A. Hawley, Asia Minor, London-New York 1918.

A. Herring, Photographing Magnesia on Meander: Image, Exhibition and Excavation, History of Photography 39, 2015, 71-87.

D. Hogarth et al., Guide to Greece, the Archipelago, Constantinople, the Coasts of Asia Minor, Crete and Cyprus, London 1908.

G. H. R. Horsley - J. M. Luxford, Pagan Angels in Roman Asia Minor: revisiting the epigraphic evidence, AS 66, 2016, 141-83.

G. Howell, Queen of the Desert: The Extraordinary Life of Gertrude Bell, London 2015.

M. P. C. Jackson, A Critical Examination of Gertrude Bell's Contribution to Archaeological Research in Central Asia Minor, in: P. T. Collins and C. Tripp (eds.), Gertrude Bell and Iraq: A Life and Legacy, Oxford 2017, 47-76.

A. Joanne - É. Isambert, Itinéraire descriptif, historique et archéologique de l'Orient v.1 Turkey, Paris 1881.

A. L. J. de Laborde, Voyage de l'Asie Mineure, Paris 1838.

É. Le Camus, Voyage aux Sept Églises de l'Apocalypse, Paris 1896.

É. Le Camus, Colosses, in: F. Vigouroux (ed.), Dictionnaire de la Bible Vol C-F, Paris 1899, 860-866.

É. Le Camus, Notre Voyage aux pays biblique: Haute Palestine, Syrie, Asie Mineure, Grèce, Paris 1899.

P.-E. Legrande - J. Chamonard, Inscriptions de Phrygie, BCH XVII, 1893, 241-93.

P. M. Fraser - E. Matthews (eds.), Lexicon of Greek Personal Names, 5 volumes, Oxford 1987-2018.

M. S. Macrakis, Introduction, in: M. S. Macrakis (ed.), Greek Letters: From Tablets to Pixels, New Castle, DE 1996, xiii-xxviii.

H. Malay - C. Tanriver, The Cult of Apollo Syrmaios and the Village of Parloai near Sattai, North-Eastern Lydia, in: M-P. de Hoz - J. P. Sánchez Hernández - C. M. Valero (eds.), Between Tarhuntas and Zeus Polieus: Cultural Crossroads in the Temples and Cults of Graeco-Roman Anatolia, Leuven 2016, 171-84. 
Mitchell 2013

Parker 2000

Quandt 1913

Ramsay 1883

Ramsay 1895

Ramsay 1897

Ramsay 1909

Ramsay - Bell 1909

Renan 1869

Ricl 1992

Ricl 2008

Ritti 2008

Rycaut 1679

Sterrett 1888

Strubbe 1997

Strzygowski 1903

Svoboda 1869

Şimşek 2002

Thonemann 2011
S. Mitchell, Further thoughts on the cult of Theos Hypsistos, in: S. Mitchell - P. Van Nuffelin (eds.), One God. Pagan Monotheism in the Roman Empire, Cambridge, 2013, 168-197.

R. Parker, Theophoric Names and the History of Greek Religion, in S. Hornblower - E. Matthews (eds.), Greek Personal Names: Their Value as Evidence, Oxford 2000, 53-79.

G. Quandt, De Baccho ab Alexandri Aetate in Asia Minore Culto, Halle 1913.

W. M. Ramsay, The Cities and Bishoprics of Phrygia, JHS 4, 1883, 370-436.

W. M. Ramsay, The Cities and Bishoprics of Phrygia, Vol. I, Oxford 1895.

W. M. Ramsay, The Cities and Bishoprics of Phrygia, Vol. II, Oxford 1897.

W. M. Ramsay, A Country Town of Lycaonia. A Description of the Conditions of Christian life under the Eastern Empire, Journal of the Transactions of the Victoria Institute 41, 1909, 36-46.

W. M. Ramsay - G. L. Bell, The Thousand and One Churches, London 1909.

E. Renan, Histoire des origines du Christianisme, Vol. 3, Paris 1869.

M. Ricl, Hosios kai Dikaios 2. Analyse, EpigrAnat 19, 1992, 71-102.

M. Ricl, Newly published and unpublished inscriptions for Hosios and Dikaios and their contribution to the study of the cult, in: E. Winter (ed.), Vom Euphrat bis zum Bosporus. Kleinasien in der Antike. Festschrift für Elmar Schwertheim zum 65. Geburtstag, Bonn 2008, 563-579.

T. Ritti, Museo Archaeologico di Denizli-Hierapolis Catalogo delle iscrizione greche e latine, Naples 2008.

P. Rycaut [Ricaut], The Present State of the Greek and Armenian Churches Anno Christi 1678, London 1679.

J. R. S. Sterrett, The Wolfe Expedition to Asia Minor (Papers of the American School of Classical Studies at Athens 3), Boston 1888.

J. Strubbe, Arai Epitymbioi. Imprecations against Desecrators of the Grave in the Greek Epitaphs of Asia Minor. A Catalogue (IK 52), Bonn 1997.

J. Strzygowski, Kleinasien, ein Neuland der Kunstgeschichte, Leipzig 1903.

A. Svoboda, The Seven Churches of Asia: with twenty full-page photographs taken on the spot, historical notes, and itinerary, London 1869.

C. Şimşek, Kolossai, Arkeoloji ve Sanat 107, 2002, 3-17.

P. Thonemann, The Maeander Valley: A Historical Geography from Antiquity to Byzantium, Cambridge 2011. 
Tracy 1990

von Aulock 1984

Weber 1891

Weber 1892

Weber 1893

Wilson 1895

S. V. Tracy, Attic Letter-Cutters of 229 to 86 B.C., Berkeley 1990.

H. von Aulock, Münzen und Städte Phrygiens, Vol. 1, Tübingen 1984.

G. Weber, Die unterirdische Lauf des Lykos bei Kolossai, MDAI(A) 16, 1891, 194-199.

G. Weber, Bas-reliefs de Laodicée et de Tripolis, Rev. arch 20, 1892, 288-290.

G. Weber, Inschriften aus Sued-Phrygien, MDAI(A) 18, 1893, 206207.

C. Wilson, Handbooks for Travellers: Asia Minor, Transcaucasia, Persia, etc, London 1895.

\section{Tartışmalı Bir Yazıt İçin Getrude Bell’in Çözümü}

Öz

İzmir'den Dinar'a giden Osmanlı tren yolu hattı üzerindeki Appa istasyonunda yazıtlı bir mezar taşı yer almaktaydı. Bu yazıt 11 yıllık bir süre zarfında üç farklı kişi tarafından kopyalanarak yayımlanmıştır. Yazıtın transkripsiyonunu yapan Georg Weber, William Mitchell Ramsay ve Georges Cousin birbirlerinden habersizdi. Üstelik, her transkripsiyon ve rekonstrüksiyon uyum içinde oldukları satır sayısından daha fazla sayıda birbirinden farklıydı. Taşın kökeni değişik yerlere atfedilmişti ve taşın şeklinin çok kısa tasvir edilmesi mezar taşının nasıl tasarlandığı konusunda büyük bir şüphe bırakmıştı. Herhangi bir çizim ya da fotoğrafı da verilmemişti. Mezar yazıtındaki isimler 'Lexicon of Greek Personal Names' tarafından bu üç yayımlı edisyonun aslında bağ kurmadığı bir yere (Sanaos) konulmuştu. Gertrude Bell tarafından 1907 yılında çekilen bir fotoğraf olmasaydı bu karmaşa çözümsüz kalabilirdi. $O$, bu yazıtı hiç yayımlamadı ama onun için yazıt Kolossai yerleşimine yaptığı başarısız bir ziyaretin uygun bir telafisi olmuştu. Fotoğrafın dikkatli bir şekilde kalitesinin artırılması ve içeriğinin sıkı bir şekilde çalışılmasıyla üç tartışmalı konu - taşın şekli, orijinal yeri ve yazıtın yazılış biçimi - büyük bir olasılıkla çözüme kavuşturulabilmektedir. Okunan yazıt, Kolossai dini yaşamının ünlü/ünsüz özelliklerinden biri olan meleklere tapınım ile bağlantı kurabileceğimiz bir isim için özellikle değerli hale gelmiştir.

Anahtar Sözcükler: Gertrude Bell, epigrafi, fotoğrafçılık, Kolossai, melekler, Osmanlı tren yolu, gezginler.

\section{Gertrude Bell's Resolution of a Disputed Inscription}

Abstract

One inscribed tombstone was placed at Appa station on the Ottoman Railway line from İzmir to Dinar. The inscription was published by three different copyists in the course of eleven years. Each person who transcribed the inscription, Georg Weber, William Mitchell Ramsay and Georges Cousin, made no acknowledgement of each other. Moreover, each transcription and reconstruction differed from the other in more lines than the number of lines in which they were in agreement; the provenance for the stone was credited to different locations and the minimal description of the form of the stone left considerable doubt as to the tombstone's design. No sketch or photograph was provided. The names on the epitaph have been assigned by the Lexicon of Greek Perso- 
nal Names to a site (Sanaos) to which none of the three published editions actually tied the inscription. The dispute might have been left unresolved, but for a photograph taken by Gertrude Bell in 1907. She never published it, but, for her, it was the fitting compensation for a failed visit to the site of Colossae. By careful enhancement of the photograph and close study of its contents, the three disputed elements - the form of the tombstone, its original location and the wording of the inscription - can be resolved to a high degree of probability. The restored inscription becomes particularly valuable for a name that may connect with one of the (in)famous features of Colossian religious life - the worship of angels.

Keywords: Gertrude Bell, epigraphy, photography, Colossae, angels, Ottoman Railway, travellers. 